\title{
PERBANDINGAN TIPE KEPRIBADIAN MUKMIN DALAM NOVEL MUNAJAT CINTA KARYA TAUFIQURRAHMAN AL-AZIZY DENGAN NOVEL PURNAMA DARI TIMUR KARYA YUDHI AW
}

\author{
Sugeng Basari \\ SMP Al-MUJTAMA' \\ sugeng310789@gmail.com
}

ABSTRAK

ABSTRACT
Tipe Kepribadian Mukmin adalah tipe kepribadian yang memiliki karakteristik beriman kepada Allah, sedangkan karakteristik keimanan tersebut berupa perilaku yang berkenaan dengan aqidah, ibadah, sosial, keluarga, moral, emosi, intelektual, pekerjaan dan fisik. Fokus penelitian dalam penelitian ini adalah menggambarkan Persamaan dan perbedaan tipe kepribadian mukmin dalam novel Munajat Cinta karya Taufiqurrahman Al-Azizy dengan novel Purnama dari Timur karya Yudhi AW. Metode yang digunakan pada penelitian ini adalah metode kualitatif, sedangkan teknik dalam kajian ini dikumpulkan dengan tenik dokementasi dan studi kepustakan. Analisis data dilakukan dengan menggunakan analisis secara induktif. Hasil penelitian ini yaitu persamaan tipe kepribadian mukmin dalam novel Munajat Cinta karya Taufiqurrahman Al-Azizy dengan novel Purnama dari Timur karya Yudhi AW adalah dideskripsikan oleh masing-masing tokoh yang melakukan perilaku beribadah kepada Allah dan bersosialisasi dengan masyrakat. Implementasi perbuatannya terletak pada jenis ibadah yang dilakukan dan tindakan sosial yang baik sesuai dengan kriteria tipe kepribadian mukmin. Perbedaan tipe kepribadian mukmin dalam novel Munajat Cinta karya Taufiqurrahman Al-Azizy dengan novel Purnama dari Timur karya Yudhi AW adalah terletak pada cara yang digunakan untuk melakukan sesuatu sesuai dengan karakter tipe kepribadian mukmin. Walaupun tujuan dari perilaku tersebut sama, namun cara yang digunakan berbeda, sehingga tipe kepribadian mukmin masing-masing tokoh memiliki perbedaan.

Kata Kunci: novel, sastra perbandingan, tipe kepribadian mukmin

Believers personality types is the characteristics of faith in Allah, whereas the form of that faith characteristic namely behaviors related to faith, worship, social, family, moral, emotional, intellectual, and physical work. The focus of this research is to describe the equation of believers personality types in novel Munajat Cinta Al-Azizy Taufiqurrahman's works and novel Purnama dari Timur Yudhi AW's works and the differences of believers personality types in novel Munajat Cinta AlAzizy Taufiqurrahman's works and novel Purnama dari Timur Yudhi AW's works. The method used in this study is a qualitative method. Techniques in this study were collected by documentation technique and Study of literature. Data analysis was performed using inductive analysis. The results of this research are equation of believers personality types in novel Munajat Cinta Al-Azizy Taufiqurrahman's works and novel Purnama dari Timur Yudhi AW's works are described by each character behavior, worship to Allah, socialize with the community. 
Implementation of the actions lies in the type of worship performed and a good social action in accordance with the criteria believerspersonality types differences of believers personality types in novel Munajat Cinta Al-Azizy Taufiqurrahman's works and novel Purnama dari Timur Yudhi AW's works is the means used to do things in accordance with the character of believer personality types. Although the purpose of the behavior is the same but the means used are different, so each the believer personality types has a different character.

Keywords: believers personality types, comparative literature, novel

PENDAHULUAN Pada hakikatnya, keberadaan manusia di dunia ini bukanlah kemauan sendiri, melainkan kehendak dari Tuhan. Manusia terlahir secara fitrah dan merupakan khalifah di muka bumi, namun manusia juga memiliki potensi menjadi manusia yang baik (taqwa) dan buruk (fujur). Potensi tersebut diperoleh dari kebebasan serta kehendak dalam diri manusia, sehingga manusia menggunakan hati dan pikiran untuk menemukan sebuah pilihan dalam menjalani kehidupan di dunia. Karakter manusia yang beraneka ragam baik dari segi perilaku dan pemikiran menjadi sebuah kepribadian yang unik. Kepribadian itu sendiri adalah totalitas individu yang menunjukkan siapa dan bagaimana manusia tersebut, bahkan tidak hanya dalam pandangan sesama manusia saja, Allah mampu mengetahui yang nampak bahkan yang tersembunyi dalam diri manusia, sehingga kepribadian seorang hamba mampu diketahui oleh-Nya. Selama ini Islam dikenal memiliki kepribadian yang baik sehingga toleransi antar umat mampu terjalin dengan baik walaupun tidak semua manusia yang memeluk agama Islam memiliki kepribadian yang baik pula. Kepribadian yang baik ini dikenal dengan istilah kepribadian mukmin.

Berbicara masalah kepribadian mukmin dan keberadaan manusia di dunia, tidak bisa dipungkiri lagi bahwa manusia merupakan piranti yang menjadi penggerak roda kehidupan dengan karakter yang dimilikinya. Eksistensi manusia sebagai makhluk individu dan sosial menjadikan manusia sebagai subyek dan obyek segala hal dalam kehidupan selama ini. Karakteristik kemanusiaan yang selama ini telah menjadi paradigma bahwa manusia mampu melakukan segala hal dengan anugerah yang luar biasa sesuai dengan kemampuan masingmasing menjadikan manusia sebagai pengisi ruang dan waktu dengan segala urusannya. Eksistensi manusia tidak hanya berada dalam ruang lingkup secara nyata, namun manusia juga menjadi pelaku dalam dunia fiktif, salah satunya dalam sebuah karya sastra.

Sastra merupakan hasil peniruan atau gambaran dari keyataan yang memiliki nilai keindahan. Karya sastra hadir di tengah-tengah masyarakat membawa pengaruh bagi aspek kehidupan manusia dan manusia dapat menyelami nuansa keindahan tersebut lewat kata-kata sebagai medium sastra, maka tidak heran jika karya satra menjadi konsumsi bagi sebagian masyarkat untuk mendapatkan kepuasan tersendiri.

Karya sastra membangun dunia melalui kata-kata, sebab katakata memiliki energi dan melalui energi itulah terbentuk citra tentang dunia tertentu. Kata yang tersusun dalam teks sebuah karya sastra merupakan medium dari karya sastra itu sendiri. Karya sastra memiliki 
struktur yang komplek, maka dari itu karya sastra harus dianalisis dengan apresiasi yang mendalam untuk mendapat nilai-nilai yang terkandung dalam sebuah karya sastra. Mengkaji sebuah karya sastra berarti mengidentifikasi bagian-bagian terpisah yang membuatnya tampak (muncul ke permukaan), menentukan hubungan antar bagian-bagian dan menemukan hubungan setiap bagian demi bagian. Berbagai genre karya sastra diantaranya puisi, prosa dan drama memiiki karakter penyampaian yang berbeda sehingga menimbulkan kesan keunikan tersendiri yang dapat diapresiasi secara mendalam.

Perkembangan sastra di Indonesia pantas mendapat acungan jempol. Banyak jenis karya sastra beredar luas dan memiliki nilai keindahan yang menarik untuk pembaca nikmati. Minat studi sastra Indonesia kian marak bahkan di Jepang studi mengenai kesastraan Indonesia telah ada sejak tahun 1960-an.

Dari sekian genre karya sastra, novel seolah menjadi pilihan yang tidak kalah menarik untuk dijadikan konsumsi bagi sebagian masyarakat yang menjadikannya sebagai asupan untuk memperoleh sesuatu. Novel merupakan salah satu jenis prosa fiksi yang sering dijumpai dan telah banyak dianalisis oleh apresiator sastra. Keunikan dari sebuah novel yaitu memiliki daya tarik tersendiri yang berbeda dengan genre sastra lainnya. Gaya penceritaan yang disampaikan dalam sebuah novel mampu membawa pembaca hanyut dalam suasana yang ada dalam sebuah novel dan mampu membawa pembaca ikut merasakan getaran peristiwa yang dirasakan oleh tokoh. Novel kaya akan makna yang tersirat maupun tersurat, maka dari itu tidak heran lagi apabila novel menjadi obyek penelitian yang menarik untuk dianalisis dan diteliti.

Berbagai jenis novel dan keunikannya telah lama berada di tengah-tengah masyarakat, misalnya novel religi yang notabene kaya akan hikmah keagamaan dan mampu menambah motivasi keimanan pembaca meningkat. Novel Munajat Cinta karya Taufiqurrahman AlAzizy dan novel Purnama dari Timur karya Yudhi AW adalah salah satu jenis novel religi yang tidak kalah menarik. Hal ini dikarenakan kedua novel ini kental dengan nilai religius dan syarat akan keimanan seorang hamba kepada Tuhannya. Gejolak dan dinamika alur cerita yang tersaji dalam novel ini memunculkan permasalahan yang berliku bagi tokoh yang berperan di dalamnya dan pada sosok tokoh inilah lahir sebuah gambaran kepribadian mengenai siapa tokoh sebenarnya, sehinnga menimbulkan alur cerita yang labih menarik apabila ditelusuri secara mendalam. Gambaran mengenai kepribadian bisa dilihat dari cara tokoh berfikir dan berperilaku, seperti halnya dalam novel Munajat Cinta. Ketika Ruwayda yang tidak lain adalah tokoh utama dalam novel ini ditanya oleh ayahnya siapa sebenarnya dirinya, dengan penuh kemantapan hati Ruwayda berkata, "Saya bukan siapa-siapa dan saya melihat kebenaran dalam firman-firmannya". Dari penggalan dialog antara ayah dan anaknya inilah bisa dilihat bahwa Ruwayda memiliki kepribadian yang bisa diklasifikasikan ke dalam tipe kepribadian mukmin dan dalam novel Purnama dari Timur yang menggambarkan sosok religious sejati, yakni Sunan Ampel dan Sunan Gresik. Maulana Malik Ibrahim adalah tokoh yang vital di dalam cerita ini. Beliau dikenal dengan sebutan Sunan Gresik. Pengetahuannya yang luas tentang Agama Islam mengambarkan kepribadian mukmin yang kuat seperti yang nampak pada kutipan berikut, "Sebagai seorang ulama, ia memiliki ilmu 
pengetahuan agama yang dapat diandalkan, selain iti ia memiliki budi pekerti yang baik. Maulana Malik Ibrahim memang seorang ulama kenamaan di tanah kelahirannya". Dari data faktual inilah, sosok tokoh tersebut memiliki kepribadian yang bisa dikategorikan ke dalam tipe kepribadian mukmin.

Novel Munajat Cinta karya Taufiqurrahman Al-Azizy merupakan novel dwilogi. Pengarang novel tersebut berdakwah secara bersahabat dan menyenangkan dengan rangkaian peristiwa yang ada di dalam novel ini. Semua karya Taufiqurrahman Al-Azizy diterima luas sehingga dinobatkan sebagai National Best-seller termasuk novel Munajat Cinta ini dan sebagian dari karyanya telah diterjemahkan ke dalam bahasa asing, namun novel Purnama dari Timur juga memiliki nilai lebih yakni menguak sejarah perjalanan Sunan Ampel dan Sunan Gresik yang menjadi pelopor utama jayanya Islam di tanah Jawa.

Penelitian ini membahas perbandingan tipe kepribadian mukmin dalam novel Munajat Cinta karya Taufiqurrahman Al-Azizy dengan novel Purnama dari Timur karya Yudhi AW. Alasan peneliti mengangkat judul ini adalah selain sangat menarik dan dinilai penting untuk dikaji, peneliti ingin menunjukkan sejauh mana perbedaan kepribadian masing-masing tokoh yang berperan dalam dua novel tersebut. Walaupun kedua novel ini memiliki tokoh yang mayoritas muslim, namun perlu diketahui bersama mereka memiliki tingkat keimanan yang berbeda. Tipe kepribadian mukmin mampu menunjukkan sosok individu secara keseluruhan dalam sebuah cerita rekaan. Peneliti meyakini bahwa tipe kepribadian mukmin dalam novel Munajat Cinta karya Taufiqurrahman Al-Azizy dan novel Purnama dari Timur karya Yudhi AW tergambar dari beberapa tokoh yang menjadi subyek cerita, baik dari segi perilaku, perkataan dan cara berfikir tokoh.

Pengkajian mengenai tipe kepribadin ini sangat bermnfaat dalam menambah wawasan keilmuan bagi pembaca, selain itu pembaca juga bisa belajar lebih mengenal dirinya sendiri. Sekaligus dengan adanya perbandingan dua novel berkualitas ini, semua pihak bisa memperdalam mengenai kepribadian masing-masing. Penelitian ini juga bermanfat sebagai bahan pembelajaran dalam dunia kesusastraan. Bertambahnya jumlah penelitian mengenai prosa khusunya novel, maka akan menambah luasnya pengetahuan pembaca terhadap kajian prosa fiksi dan analisinya.

Penelitian ini memiliki tujuan yaitu mendeskripsikan persamaan tipe kepribadian mukmin dalam novel Munajat Cinta karya Taufiqurrahman Al-Azizy dengan novel Purnama dari Timur karya Yudhi AW. Disisi lain, mendeskripsikan Perbedaan tipe kepribadian mukmin dalam novel Munajat Cinta karya Taufiqurrahman Al-Azizy dengan novel Purnama dari Timur karya Yudhi AW merupakan tujuan berikutnya. Secara keseluruhan maka dapat disimpulkan bahwa tujuan dari penilitian menggambarkan persamaan sekaligus perbedaan Tipe Kepribadian Mukmin dalam Novel Munajat Cinta karya Taufiqurrahman Al-Azizy dengan Novel Purnama dari Timur karya Yudhi AW.

Manfaat yang diharapkan dari penelitian ini adalah manfaat secara teoritis, penelitian ini sangat bermanfaat dalam rangka menerapkan keilmuan (teori) yang diperoleh selama di bangku kuliah. Selain itu, manfaat yang tidak kalah penting yakni manfaat praktis, 
secara praktis penelitian ini bermanfaat sebagai gambaran atau pengetahuan tentang karya sastra bergenre cerpen dan novel, sehingga menimbulkan sikap kritis terhadap muatan dan fenomena yang ada.

METODE

Penelitian ini menggunakan teknik dokumentasi, teknik studi kepustakaan, dan komparasi. Teknik pengumpulan data adalah rangkaian kegiatan yang dilaksanakan untuk menyelesaikan laporan penelitian. Teknik pengumpulan data dalam penelitian ini menggunakan teknik dokumentasi, teknik studi kepustakaan, dan komparasi dengan beberapa langkah, yaitu membaca secara keseluruhan isi novel Munajat Cinta karya Taufiqurrahman Al-Azizy dan novel Purnama dari Timur karya Yudhi AW, mengidentifikasi kutipan yang berisi tipe kepribadian mukmin dalam novel Munajat Cinta karya Taufiqurrahman Al-Azizy dan novel Purnama dari Timur karya Yudhi AW, mengkomparasikan persamaan dan perbedaan kutipan tersebut sesuai kriteria tipe kepribadian mukmin.

Pendekatan penelitian ini berangkat dari teori psikologi agama yang menyatakan bahwa manusia sebagai obyek yang menjadi kajian psikologi dilihat dari tingkahlaku beragama. Manusia dianggap memiliki potensi beragama sehingga dalam perilaku beragama tersebut menjadi sasaran pendekatan dengan menggunakan tipe kepribadian mukmin sebagai pisau bedah penelitian.

Sumber data dalam penelitian ini adalah novel Munajat Cinta karya Taufiqurrahman Al-Azizy yang diterbitkan oleh Diva Press pada bulan April 2008 serta memiliki tebal halaman sebanyak 466 halaman. Novel ini menceritakan sebuah perjalanan hidup seorang hamba yang mencari sebuah jalan kebenaran dan proses pencarian jati diri seorang muslim yang sejati. Tokoh utama dalam novel ini adalah Ruwayda, seorang gadis yang memang memiliki latar belakang prestasi membanggakan. Terlahir dari keluarga yang mapan, namun pada akhirnya sebuah ujian besarpun datang sehingga perjalanannya baru dimulai. Selain novel Munajat Cinta, sumber data dalam penelitian ini adalah novel Purnama dari Timur karya Yudhi AW yang diterbitkan oleh Diva Press pada bulan juli 2011 dengan jumlah halaman sebanyak 382. Novel ini menceritakan sejarah penyebaran agama Islam di Tanah Jawa yang dipelopori oleh Sunan Ampel dan Sunan Gresik. Beliau memulai penyebaran agama Islam ini dan kemudian mengubah peta politik pada waktu itu. Kisah yang memang menjadi sorotan paling menarik ketika perjalanan hidup beliau tidaklah mudah sebagai wali yang menyebarkan Agama Islam, namun keberhasilan tersebut masih bisa dilihat dari jumlah mayoritas pemeluk agama Islam di Indonesia.

Objek penelitian dalam penelitian ini dapat berupa kata-kata, frasa, klausa, kalimat, dan paragraf yang sesuai dengan kriteria tipe kepribadian mukmin dalam novel Munajat Cinta karya Taufiqurrahman Al-Azizy dan novel Purnama dari Timur karya Yudhi AW. Dari data yang menjadi obyek penelitian tersebut disesuaikan dengan fokus penelitian, yaitu persamaan dan perbedaan tipe kepribadian mukmin dalam novel Munajat Cinta karya Taufiqurrahman Al-Azizy dan novel Purnama dari Timur karya Yudhi AW.

Analisis data adalah upaya yang dilakukan dengan jalan mengorganisasikan data, memilah satuan data yang dapat dikelola, mensintesis data. Analisis ini merupakan pembuktian abstraksi 
berdasarkan bagian yang telah dikumpulkan. Peneliti kembali melakukan pemeriksaan data untuk dideskripsikan pada tahap selanjutnya.

PEMBAHASAN

\author{
PEMBAHASAN
}

Berdasarkan analisis persamaan dan perbedaan tipe kepribadian mukmin dalam novel Munajat Cinta karya Taufiqurrahman Al-Azizy dan novel Purnama dari Timur karya Yudhi AW, ditemukan letak persamaan sekaligus perbedaan.

\section{Identifikasi dan Klasifikasi Data}

Berikut ini adalah data-data terkait tentang persamaan dan perbedaan tipe kepribadian mukmin dalam novel Munajat Cinta karya Taufiqurrahman Al-Azizy dan novel Purnama dari Timur karya Yudhi AW.

Dan ketika jati dirimu telah engkau temukan, saat itulah Allah akan menurunkan rahmat-Nya kepadamu dan kepada orang tuamu (Al-Azizy, 2008:7).

Ketiga ulama Persia ini mengajak orang muslim Gujarat untuk lebih giat beribadah kepada Allah (Yudhi, 2011:15).

Kedua kutipan di atas merupakan data tipe kepribadian mukmin yang memiliki persamaan.

Doakan saya bu, Assalamu'alaikum...

Wa'alaikum salam (Al-Azizy, 2008:43).

Assalamu'alaikum, sapa Maulana Malik Ibrahim...

Wa'alaikumsalam, Jawabnya (Yudhi, 2011:18).

Kedua kutipan di atas merupakan data tipe kepribadian mukmin yang memiliki persamaan.

Yang jelas kedua orang tua saya telah lama memaafkan saya (AlAzizy, 2008:58).

Ia pegang pundak penjalin dengan tangan kanannya sambil tersenyum (Yudhi, 2011:56).

Kedua kutipan di atas memiliki letak persamaan, yaitu apabila dilihat dari segi kehidupan sosial, ciri dari tipe kepribadian mukmin adalah saling memaafkan dan welas asih antar sesama.

Bu Istiqomah bertanya dan menganggap aku sebagai anaknya (AlAzizy, 2008:60).

Merekapun berpelukan sebelum berpisah (Yudhi, 2011:43).

Letak persamaan tipe kepribadian mukmin juga tergambar dari kedua kutipan di atas, yaitu memiliki hubungan persaudaraan yang baik antar manusia merupakan salah satu ciri dari tipe kepribadian mukmin dilihat dari segi sosial.

Hatiku berdzikir dan terus berdzikir (Al-Azizy, 2008:68). 
Tangannya sibuk dengan untaian tasbih yang ia pakai untuk menyebut Asma Allah dala dzikirnya (Yudhi, 2011:17).

Selain dalam kehidupan sosial, nilai ibadah merupakan cermin utama dalam mengkaji tipe kepribadian mukmin. Dua kutipan di atas memiliki persamaan, yaitu keduanya menunjukkan adanya aktifitas atau perilaku beribadah.

Pak Habiburrahman adalah orang yang sering memberikan saran dan ajaran kepadaku (Al-Azizy, 2008:12).

Raden Rahmat kian disukai oleh jamaah karena gaya dakwahnya yang santun dan menghormati adat istiadat setempat (Yudhi, 2011:242).

Kedua kutipan di atas merupakan data tipe kepribadian mukmin yang memiliki perbedaan.

Sahabat-sahabatku di LSM sekarang ini tengah berupaya memberikan pelajaran kepada ayah tiri Lis (Al-Azizy, 2008:312). Bersama-sama, mereka menunjukkan sifat sosial yang tinggi kepada masyarakat, suka menolong siapa saja yang membutuhkan pertolongan tanpa meminta imbalan apapun (Yudhi, 2011:62).

Kedua kutipan di atas merupakan data tipe kepribadian mukmin yang memiliki perbedaan.

\section{Interpretasi Data Persamaan dan Perbedaan Tipe Kepribadian Mukmin}

Sesuai dengan data yang telah diidentifikasi dan diklasifikasikan menurut kajian teori yang digunakan, dapat dideskripsikan interpretasi data persamaan tipe kepribadian mukmin dalam novel Munajat Cinta karya Taufiqurrahman Al-Azizy dengan novel Purnama dari Timur karya Yudhi AW sebagai berikut.

Dan ketika jati dirimu telah engkau temukan, saat itulah Allah akan menurunkan rahmat-Nya kepadamu dan kepada orang tuamu (Al-Azizy, 2008:7).

"Ketiga ulama Persia ini mengajak orang muslim Gujarat untuk lebih giat beribadah kepada Allah" (Yudhi, 2011:15).

Kedua kutipan di atas memiliki persamaan tipe kepribadian mukmin yang ditunjukkan oleh tokoh. Letak persamaannya adalah dalam kedua kutipan di atas terdapat ajakan untuk berbuat baik. Ruwayda sebagai tokoh utama dalam novel Munajat Cinta diajak untuk lebih mengenal dirinya sendiri, sedangkan dalam novel Purnama dari Timur ketiga ulama mengajak untuk lebih giat beribadah.

Doakan saya bu, Assalamu'alaikum...

Wa'alaikum salam (Al-Azizy, 2008:43). 
Assalamu'alaikum, sapa Maulana Malik Ibrahim...

Wa'alaikumsalam, jawabnya (Yudhi, 2011:18).

Persamaan tipe kepribadian mukmin ditunjukkan juga dalam kutipan di atas. Kedua kutipan di atas memiliki letak persamaan, yakni keduanya sama-sama mengucapkan dan menjawab salam antar sesama muslim.

Menjalin rasa kasih sayang antar sesama merupakan salah satu perilaku yang baik ketika menjalin interaksi dalam kehidupan sosial. Saling memaafkan satu sama lainnya dan membuka lembaran baru merupakan kekuatan silaturrahmi yang akan membawa kedamain. Manusia tidak luput dari salah dan dosa selama menjalin hubungan dengan orang lain. Memaafkan adalah upaya mampu menerima kesalahan orang lain sebelum atau sesudah orang tersebut meminta maaf. Salah satu tipe kepribadian mukmin berkenaan dengan kehidupan sosial adalah saling memaafkan. Kutipan di bawah ini, adalah kutipan yang terdapat di dalam novel Munajat Cinta karya Taufiqurrahman Al-Azizy. Gambaran mengenai tipe kepribadian mukmin tampak ketika Ibu Raudoh mengatakan bahwa kedua orrang tuanya telah memaafkan kesalahannya. Secara factual, kutipan ini telah menggambarkan adanya tipe kepribadian mukmin. Adapun kutipan yang dimaksud adalah sebagai berikut.

Yang jelas kedua orang tua saya telah lama memaafkan saya (AlAzizy, 2008:58).

Kutipan di atas memiliki persamaan dengan kutipan yang terdapat di dalam novel Purnama dari Timur karya Yudhi AW. Di bawah ini merupakan kutipan novel Purnama dari Timur yang menggambarkan adanya tipe kepribadian mukmin berkenaan dengan kehidupan sosial, yaitu saling memaafkan kesalahan orang lain. Dikisahkan bahwa Maulana Malik Ibrahim memaafkan Penjalin dan anak buahnya yang berupaya mencelakakan Maulana Malik Ibrahim beserta rombongannya ketika melakukan perjalanan. Perilaku yang memaafkan yang demikian adalah salah satu kriteria tipe kepribadian mukmin. Adapun kutipan yang dimaksud adalah sebagai berikut.

Ia pegang pundak penjalin dengan tangan kanannya sambil tersenyum (Yudhi, 2011:56).

Kesimpulannya adalah kedua kutipan di atas memiliki persamaan. Letak persamaannya terdapat pada pendeskripsian tipe kepribadian mukmin berkenaan dengan kehidupan sosial yaitu saling memaafkan kesalahan orang lain, sehingga keduanya benar-benar memiliki persamaan.

Selain menyeru kepada kebaikan dan saling memaafkan, salah satu kriteria tipe keperibadian mukmin berkenaan dengan kehidupan sosial yaitu mengasihi satu sama lain. Manusia adalah saudara baik yang seiman ataupun yang tidak seiman. Mukmin dihimbau untuk saling menyayangi satu sama lainnya, sehingga ketentramanpun akan tercipta sepanjang perjalanan hidup manusia yang beriman. Kutipan di bawah ini merupakan kutipan yang terdapat di dalam novel Munajat Cinta karya Taufiqurrahman Al-Azizy. Kutipan tersebut menceritakan bahwa $\mathrm{Bu}$ 
Istiqoamah yang tidak lain adalah seorang yang baru dikenal Ruwayda ketika memulai perjalanan untuk mencari Pak Burhan. Bu Istiqomah sangat menyayangi Ruwayda seperti menyayangi anaknya sendiri. Rasa saling menyayangi tersebutlah yang merupakan salah satu kriteria tipe kepribadian mukmin berkenaan dengan kehidupan sosial. Adapun kutipannya adalah sebagai berikut.

Bu Istiqomah bertanya dan menganggap aku sebagai anaknya (AlAzizy, 2008:60).

Kutipan di atas memiliki persamaan dengan kutipan yang terdapat di dalam novel Purnama dari Timur karya Yudhi AW. Diceritakan saat Maulana Malik Ibrahim berpisah dengan para ulama lain demi menyebarkan agama Islam di tanah Jawa. Mereka saling berpelukan sambil saling mendoakan satu sama lainnya. Jalinan rasa kasih sayang inilah yang merupakan salah satu kriteria tipe kepribadian mukmin. Adapun kutipan yang dimaksud adalah sebagai berikut.

Merekapun berpelukan sebelum berpisah (Yudhi, 2011:43).

Kesimpulannya adalah kedua kutipan di atas memiliki persamaan yaitu sama-sama mendekripsikan adanya tipe kepribadian mukmin dari masing-masing kutipan. Persamaannya terletak pada tipe kepribadian mukmin berkenaan dengan kehidupan sosial, yaitu saling menyayangi satu sama lain karena sesungguhnya manusia adalah saudara dengan manusia lainnya.

Salah satu karakter tipe kepribadian mumin berkenaan dengan ibadah adalah melaksanakan kegiatan ibadah, seperti shalat, dzikir, dan puasa. Beribadah kepada Allah merupakan sebuah keharusan untuk mendapatkan pahala dan menghapus sebagian dari dosa manusia. Beribadah dengan khusuk dapat meningkatkan kedekatan seorang hamba kepada Allah Swt. Beribadah dengan baik, menunjukkan seorang hamba memiliki tipe kepribadian mukmin yang baik pula. Kutipan di bawah ini merupakan kutipan dari novel Munajat Cinta karya Taufiqurrahman AlAzizy. Diceritakan bahwa ketika Ruwayda mengalami ketakutan luat biasa saat melewati sebuah jalan yang sepi dan gelap, dia berdzikir dan perilaku demikian sesuai dengan tipe kepribadian mukmin berkenaan dengan ibadah yaitu melaksanakan ibadah sesuai dengan yang telah diperintahkan oleh Allah. Adapun kutipan yang dimaksud adalah sebagai berikut.

Hatiku berdzikir dan terus berdzikir (Al-Azizy, 2008:68).

Kutipan di atas memiliki persamaan dengan kutipan yang terdapat di dalam novel Purnama dari Timur karya Yudhi AW di bawah ini. Kutipan tersebut memberikan gambaran persamaan. Diceritakan bahwa ketika selesai melaksanakan shalat fardu, Maulana Malik Ibrahim berdzikir dengn khusuk menyebut nama Allah. Adapun kutipannya adalah sebagai berikut.

Tangannya sibuk dengan untaian tasbih yang ia pakai untuk menyebut Asma Allah dala dzikirnya (Yudhi, 2011:17). 
Kesimpulannya adalah kedua kutipan di atas sama-sama memiliki persamaan, yaitu memiliki tipe kepribadian mukmin dilihat dari perilaku tokoh yang ditunjukkan dengan ibadahnya kepada Allah. Ibadah tersebut sesuai dengan karakter atau tipe kepribadian mukmin berkenaan dengan ibadah.

Pak Habiburrahman adalah orang yang sering memberikan saran dan ajaran kepadaku (Al-Azizy, 2008:12).

Raden Rahmat kian disukai oleh jamaah karena gaya dakwahnya yang santun dan menghormati adat istiadat setempat (Yudhi, 2011:242).

Kedua kutipan di atas memang merupakan gambaran dari tipe kepribadian mukmin, namun memiliki perbedaan dati segi cara penyampaian dakwah yang berbeda sekaligus sasaran penerima dakwah yang jauh berbeda.

Sahabat-sahabatku di LSM sekarang ini tengah berupaya memberikan pelajaran kepada ayah tiri Lis (Al-Azizy, 2008:312). Bersama-sama, mereka menunjukkan sifat sosial yang tinggi kepada masyarakat, suka menolong siapa saja yang membutuhkan pertolongan tanpa meminta imbalan apapun (Yudhi, 2011:62).

Kedua kutipan di atas juga merupakan gambaran dari tipe kepribadian mukmin, namun letak perbedaannya adalah cara yang dilakukan. Keduanya sama bertujuan untuk menolong, namun langkah dan tujuan yang jauh berbeda sangat tampak dalam kutipan di atas.

SIMPULAN

Berdasarkan pembahasan, dapat disimpulkan bahwa terdapat persamaan dan perbedaan tipe kepribadian mukmin di dalam novel Munajat Cinta karya Taufiqurrahman Al-Azizy dengan novel Purnama dari Timur karya Yudhi AW. Persamaan tipe kepribadian mukmin yang terdapat di dalam novel tersebut, dideskripsikan oleh masing-masing tokoh yang melakukan perilaku beribadah kepada Allah, bersosialisasi dengan masyrakat sehingga implementasi perbuatannya terletak pada jenis ibadah yang dilakukan dan tindakan sosial yang baik sesuai dengan kriteria tipe kepribadian mukmin.

\section{DAFTAR PUSTAKA}

Ahyadi, Abdul Aziz. 1995. Psikologi Agama Kepribadian Muslim Pancasila. Bandung: Sinar Baru Algensindo.

Aminuddin. 2013. Pengantar Apresiasi Sastra. Bandung: Sinar Baru Algensindo Offset.

Aminuddin. 2000. Pengantar Apresiasi Karya Sastra. Bandung: Sinar Baru Aglesindo.
Atmosuwito, Subijantoro. 2010. Perihal Sastra dan Religiuitas dalam Sastra. Bandung: Sinar Baru Algensindo.

AW, Yudhi. 2011. Purnama dari Timur. Jogjakarta: Diva Press.

Al-Azyzy. Taufiurrahman. 2008. Munajat Cinta. Jogjakarta: Diva Press.

Moleong, Lexy J. 2006. Metodologi Penelitian Kualitatif. Bandung: PT Remaja Rosdakarya. 
Perbandingan Tipe Kepribadian Mukmin Dalam Novel Munajat Cinta Karya Taufiqurrahman Al-Azizy Dengan Novel Purnama Dari Timur Karya Yudhi Aw

Moleong, Lexy J. 2010. Penelitian Kualitatif Metodologi. Bandung: PT Remaja Rosdakarya.

Natia, I.K. 2010. Apresiasi Sastra Indonesia. Surabaya: Bintang.

Nurgiyantoro, Burhan. 1995. Teori Pengkajian Fiksi. Yogyakarata: Gadjah Mada University Press. 